\title{
CADASTRAL MAPS OF IRRIGATED AREAS BY CENTER PIVOTS IN THE STATE OF MINAS GERAIS, USING CBERS-2B/CCD SATELLITE IMAGING
}

\author{
ELIZABETH FERREIRA ${ }^{1}$, JOICE H. DE TOLEDO ${ }^{2}$, ANTONIO A. A. DANTAS ${ }^{3}$, \\ RAFAEL M. PEREIRA ${ }^{4}$
}

\begin{abstract}
Medium-resolution satellite images have been widely used for the identification and quantification of irrigated areas by center pivot. These areas, which present predominantly circular forms, can be easily identified by visual analyses of these images. In addition to identifying and quantifying areas irrigated by center pivot, other information that is associated to these areas is fundamental for producing cadastral maps. The goal of this work was to generate cadastral mapping of areas irrigated by center pivots in the State of Minas Gerais, Brazil, with the purpose of supplying information on irrigated agriculture. Using the satellite CBERS2B/CCD, images were used to identify and quantify irrigated areas and then associate these areas with a database containing information about: irrigated area, perimeter, municipality, path row, basin in which the pivot is located, and the date of image acquisition.3,781 center pivots systems were identified. The smallest area irrigated was 4.6 hectares and the largest one was 192.6 hectares. The total estimated value of irrigated area was 254,875 hectares. The largest number of center pivots appeared in the municipalities of Unaí and Paracatu, with 495 and 459 systems, respectively. Cadastral mapping is a very useful tool to assist and enhance information on irrigated agriculture in the State of Minas Gerais.
\end{abstract}

KEYWORDS: irrigated agriculture, remote sensing, geographic information system (GIS), image visual interpretation.

\section{CADASTRO DAS ÁREAS IRRIGADAS POR PIVÔS CENTRAIS, EM MINAS GERAIS, UTILIZANDO IMAGENS DO SATÉLITE CBERS-2B/CCD}

RESUMO: As imagens de satélite de média resolução são bastante utilizadas para a identificação e quantificação de áreas irrigadas por pivô central. Essas áreas, por apresentarem formas predominantemente circulares, podem ser facilmente identificadas por meio de análises visuais dessas imagens. Além da identificação e quantificação das áreas irrigadas por pivô, a adição de outras informações complementares a estas áreas é fundamental para gerar mapas cadastrais. $\mathrm{O}$ objetivo deste trabalho foi gerar um mapeamento cadastral das áreas irrigadas por pivôs centrais no Estado de Minas Gerais com a finalidade de suprir a carência de informações relativas à agricultura irrigada. Utilizando imagens do satélite CBERS2B/CCD, foi feita a identificação e quantificação das áreas irrigadas e, em seguida, foi associado um banco de dados contendo informações sobre: a área irrigada, o perímetro, o município, a órbita-ponto, a bacia hidrográfica na qual o pivô está localizado e a data de aquisição da imagem. Foram identificados 3.781 sistemas de pivôs centrais. A menor área irrigada foi de 4,6 hectares, e a maior foi de 192,6 hectares. O valor total estimado de área irrigada foi de 254.875 hectares. O maior número de pivôs centrais apareceu nos municípios de Unaí e Paracatu, que apresentaram 495 e 459 sistemas, respectivamente. O mapeamento cadastral é uma ferramenta muito útil para auxiliar e aumentar a informação sobre a agricultura irrigada no Estado de Minas Gerais.

PALAVRAS-CHAVE: agricultura irrigada, sensoriamento remoto, sistema de informação geográfica (SIG), interpretação visual de imagens.

\footnotetext{
${ }^{1}$ Eng $^{\mathrm{a}}$ Agrícola, Profa. Dra., Departamento de Engenharia, UFLA, Lavras - MG, Fone: (0XX35) 3829.1481, bethf@ deg.ufla.br.

${ }^{2}$ Eng $^{\mathrm{a}}$ Agrícola, Bolsista de Apoio Técnico da FAPEMIG,UFLA, Lavras - MG.

${ }^{3}$ Habilitado em Técnicas Agropecuárias, Prof. Dr., Departamento de Engenharia, UFLA, Lavras - MG.

${ }^{4}$ Graduando em Agronomia, Bolsista Iniciação Científica, UFLA, Lavras - MG.

Recebido pelo Conselho Editorial em: 14-12-2010

Aprovado pelo Conselho Editorial em: 20-5-2011
}

Eng. Agríc., Jaboticabal, v.31, n.4, p.771-780, jul./ago. 2011 


\section{INTRODUCTION}

Irrigated agriculture is the major consumer of freshwater resources in the world and it accounts for more than $70 \%$ of the water withdrawn from lakes, rivers and groundwater (CAI \& ROSEGRANT, 2002).

According to OLIVEIRA \& TALAMINI (2010), the main methods of irrigation in the Brazilian agriculture are: furrow irrigation or drainage, used in $33.8 \%$ of the irrigated area, central pivot, present in $21.8 \%$ of the irrigated area, conventional sprinkler, used in $18.8 \%$ of the irrigated area, and surface irrigation, accounting for $18.1 \%$ of the irrigated area. The method applied in the smallest scale is localized irrigation, equivalent to $7.5 \%$ of the irrigated area in Brazil.

CHRISTOFIDIS (2008) estimated that, the irrigated area totaled 350,200 hectares in the state of Minas Gerais in 2003/2004, and the method of central pivot irrigation amounted to 89,430 hectares. The author also cited that the difficulty in obtaining sufficient water available to meet both the existing areas and for new projects would be one of the obstacles to the expansion of irrigation.

With the need for a rational use of water resources for various purposes, remote sensing and geographic information systems (GIS) are important tools for monitoring activities related to water usage, such as irrigated agriculture with central pivot.

In a review on the use of remote sensing data in monitoring irrigation, OZDOGAN et al. (2010) concluded that studies in this area still are in an intermediate stage of development, at the local scale. The authors claim that there is a consensus on the effectiveness of using vegetation indices in the identification of irrigated areas. In addition, images of a single date, acquired at the peak of growth may be sufficient to identify irrigated land, although data are necessary for an improved multi-temporal classification, and to distinguish different types of crops.

Satellite images of medium resolution are widely used for identification and quantification of areas irrigated by center pivot. This system can be easily identified by visual analysis because of its predominantly circular geometry.

SCHMIDT et al. (2004) identified 2485 central pivots in the state of Minas Gerais by using techniques of visual interpretation of images. The authors used mosaics images of the Landsat satellite from the year 2001, released by the Brazilian Agricultural Research Corporation (EMBRAPA), and concluded that the technique was appropriate to carry out the survey.

In the Distrito Federal region, SANO et al. (2005) also applied techniques of visual interpretation and manual scanning of Landsat5-TM images dated of 1992 and 2002 for a survey of the areas irrigated by center pivot. The authors identified an increase in the area irrigated by central pivot, which went from 55 to 104 units during this period.

BRAGA \& OLIVEIRA (2005) used CBERS/CCD images to identify center pivots and to analyze the area occupied by these systems in the municipality of Miguelópolis, state of São Paulo, by assessing the changes occurred between 2002 and 2004. After the end of the Landsat 7 operations in May 2003, and due to the low quality of the Landsat 5 images, which limited their use at certain times, satellite images of the China-Brazil satellite for land resources (CBERS) were viable for studies related to identification of agricultural areas in Brazil.

The CCD sensor of the CBERS-2B satellite provides images of a range of $113 \mathrm{~km}$ wide on the ground, with spatial resolution of $20 \mathrm{~m}$ and temporal resolution of 26 days. The sensor bands include blue $(0.45$ to $0.52 \mu \mathrm{m})$, green $(0.52$ to $0.59 \mu \mathrm{m})$ and red $(0.63$ to $0.69 \mu \mathrm{m})$ of the visible spectrum, as well as near infrared $(0.77$ to $0.89 \mu \mathrm{m})$, and panchromatic $(0.51$ to $0.73 \mu \mathrm{m})$, according to PONZONI \& ALBUQUERQUE (2008).

In addition to the importance of identifying and quantifying areas irrigated by center pivots, it is fundamental that information is associated with these areas, generating cadastral maps. In cadastral maps, each element is considered a geographic object, with associated attributes that can be graphically represented in several ways. Given a set of geographic regions $R_{1}, \ldots R_{n}$ and a set of 
attribute domains $A_{1}, \ldots A_{m}$, it is define a geographical object (geo-object) as an object go $=\left[a_{1}\right.$. . $. a_{m}, r_{1}, \ldots, r_{n}$, where $a_{i} \in A_{i}$ is the value of your domain attribute in the attribute $A_{i}$, and $r_{i} \in \mathrm{Ri}$ indicates the representation associated with the geo-object in the geographical region $\mathrm{R}_{\mathrm{i}}$. Therefore, a geographic object is a unique element that has descriptive attributes and can be represented in many different maps. As an example, lots of cities are elements of the geographical area that have attributes such as owner name, address, market value, among other parameters (CÂMARA et al., 1996).

In the study by XAVIER \& BASTOS (2010), cadastral maps are defined as two-dimensional (analog or digital) graphical representations of the key defining elements of the urban fabric such as streets, squares, plazas and other public spaces. Cadastral maps or plans are, in general, city documents collection representing the morphology of the city in various historical periods. These maps can be generated to compose a time series related to different topics to allow monitoring, evaluating and performing quick temporal queries on these issues.

CURADO \& FERREIRA (2003) generated cadastral maps of rural properties in the State of Tocantins, with areas above 10 hectares, registered with the National Institute of Colonization and Agrarian Reform (INCRA) before and after the year 2001, respectively. Of the 117 registered properties before 2001, only $22 \%$ had been settled by 2002 and the authors concluded that before 2001 there were records of buildings that existed only on paper (land grabbing). This land situation was evident in the analysis of the municipalities of Babaçulândia and Tocantinópolis, and that some of these areas were five times larger than the area of each municipality.

CURADO et al. (2004) conducted a cadastral mapping of rural properties in order to provide information on land use and occupation of two sub-basins in the municipality of Lavras, MG, integrating socio-economic and environmental aspects. The authors used IBGE plano-altimetric maps from 1969, georeferenced digital orthophotos from 1985, and information on socio-economic development of 2002, and compared with data collected in 1997 by the Minas Gerais Sanitation Company. These data and maps were made available for consultation in the SPRINGWEB application.

In this context, the present study aimed at identifying, through CBERS-2B/CCD images, areas irrigated by center pivot system, and building a database for storing location information and other attributes (area, perimeter, average altitude, etc.) associated with each pivot, with the goal of supplying information in the state of Minas Gerais relative to irrigated agriculture.

\section{MATERIAL AND METHODS}

The study area was the state of Minas Gerais, which is located between the geographic coordinates $14^{\circ} 00^{\prime}$ and $24^{\circ} 00^{\prime}$ latitude south and $51^{\circ} 15^{\prime}$ and $39^{\circ} 25^{\prime}$ longitude west of Greenwich. The state has an area of $586,523 \mathrm{~km}^{2}$, representing $6.9 \%$ of the country, divided into 853 municipalities. The region is predominantly of tropical climate with an average annual temperature of $21^{\circ} \mathrm{C}$, with little variation.

For the execution of this work, 86 scenes from the CBERS-2B satellite, CCD sensor, were used to cover the state of Minas Gerais. The scenes were obtained between January 4, 2008 and February 2, 2010. Initially, only scenes obtained in 2008 would be evaluated, but due to the low quality of some images or problems with the files of the scenes, it was necessary to integrate scenes with later date to cover the entire state of Minas Gerais.

Figure 1 show the grid of CBERS/CCD with path rows and dates on which of the images were acquired. It may be noticed that most of the images was obtained in 2008 (yellow tones), three scenes were acquired in 2009 (orange tones) and only the path row 155/123 belongs to the year 2010 (red). 


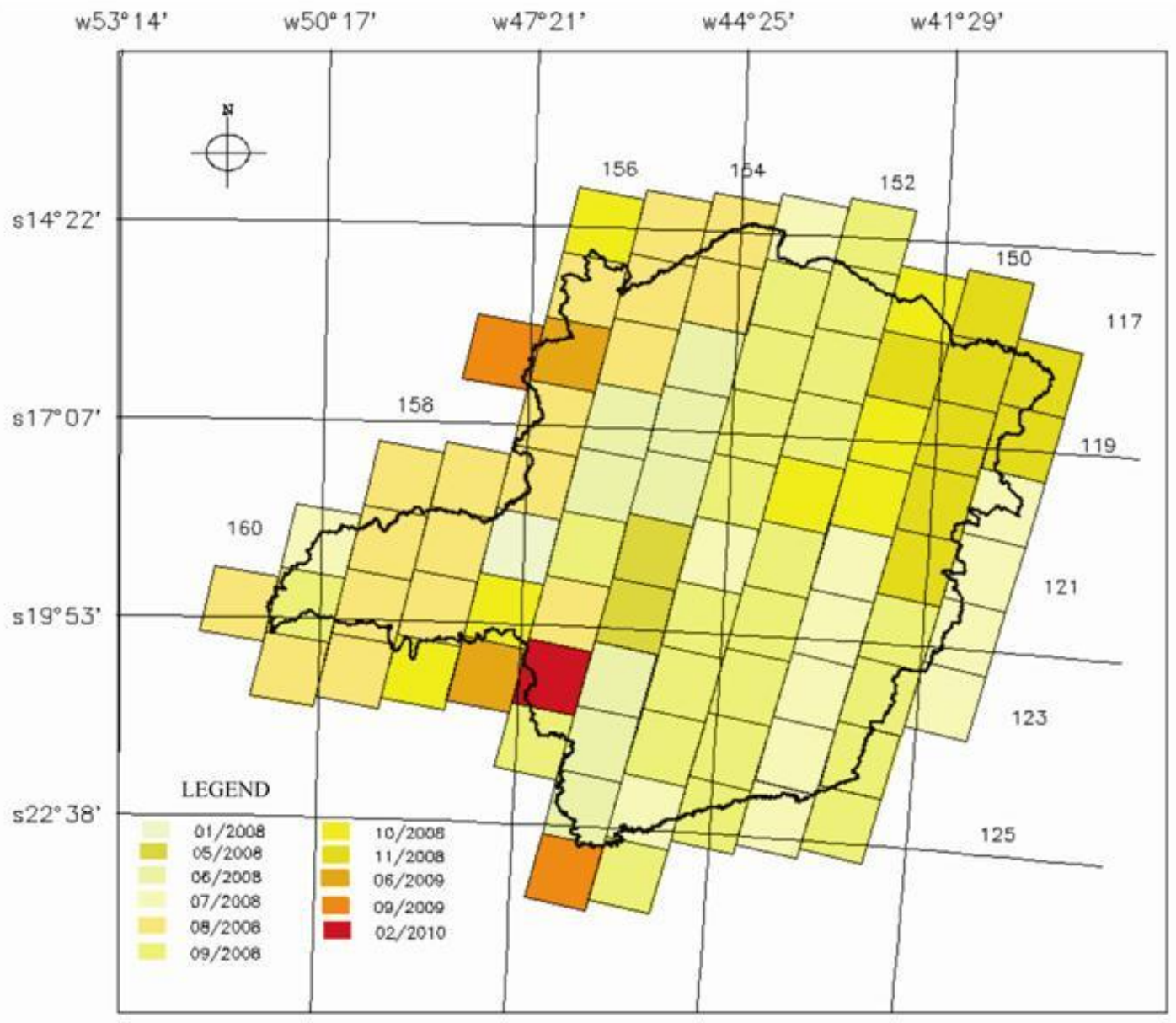

FIGURE 1. Grid location (path row) of images from CBERS/CCD satellite for Minas Gerais State with identification of the month / year of the image used in the study.

The images were obtained through the World Wide Web, where they are freely available from the Imaging Division of the National Institute for Space Research (DG /INPE). To facilitate the work and minimize interpretation errors of quantification, images were chosen with the minimum percentage of clouds.

The scenes were georeferenced using GEOCOVER mosaics of the LANDSAT 7 satellite through the routine CBERS_AUTOREG of the ENVI 4.7 software (Environment for Visualizing Images). The design of the irrigated areas was carried out using the ellipse-traced tool of ENVI to generate vector files. In addition to the files containing the pivots, the database used in the project contains vector files in shapefile format (CBERS grid, planning units, division state and municipal) and image files (images from CBERS2B/CCD and GEOCOVER).

Table 1 shows the names, description, source and type of data used in the project. Through the resources of ENVI 4.7 software, image quality was visually verified. Color composites of images in $\mathrm{RGB} / 432$ were used for visual interpretation and delimitation of areas irrigated by center pivot, as shown in Figure 2. 
TABLE 1. Project database.

\begin{tabular}{|c|c|c|c|}
\hline Name & Description & Source & Data type \\
\hline CBERS Grid & $\begin{array}{l}\text { Positioning grid of the scenes of CBERS satellite } \\
\text { passage }\end{array}$ & ENGESAT & vector \\
\hline UP & $\begin{array}{l}\text { Planning and Management units of water resources } \\
\text { in Minas Gerais State }\end{array}$ & IGAM & vector \\
\hline State Line & State Division of Minas Gerais State & GEOMINAS & vector \\
\hline Municipal Margins & $\begin{array}{l}\text { Political-Administration Division of Minas Gerais } \\
\text { State }\end{array}$ & GEOMINAS & vector \\
\hline $\begin{array}{l}\text { CBERS2B/CCD } \\
\text { Images }\end{array}$ & $\begin{array}{l}\text { Spatial resolution images o } 20 \times 20 \mathrm{~m} \text { and } \\
\text { dimension of } 113 \times 113 \mathrm{~km}\end{array}$ & INPE & matrix \\
\hline Geocover Images & Orthorectified Landsat mosaics, pixel of $14.25 \mathrm{~m}$ & NASA & matrix \\
\hline
\end{tabular}

In the database, information about area and perimeter of the pivots, in which municipality they are located, planning unit, path row and data from the scene used were associated with each irrigation system, producing a table with all these attributes. In this table, the columns contain the attributes and each row corresponds to each pivot unit identified.

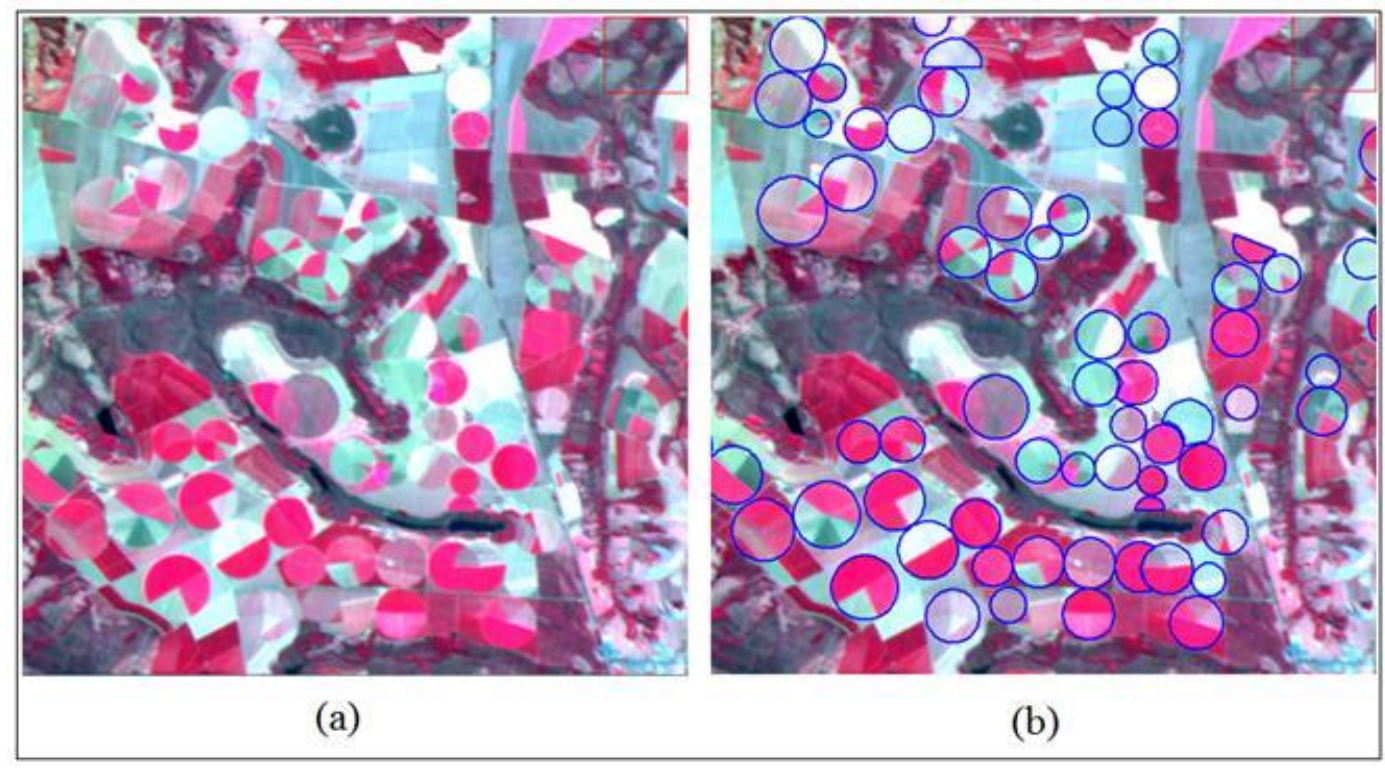

FIGURE 2. Center pivots viewed in CBERS-2B/CCD imaging, RGB/432, 155/122 path-row. (a) Raster image and (b) Vector image.

The information contained in the database is described in Table 2. The ArcGIS software version 10.0 was later used to link the scene databases, through the merge tool, forming a single file containing all the information of the areas irrigated by center pivots in Minas Gerais.

TABLE 2. Description of the contents in the cadastral mapping database.

\begin{tabular}{ll}
\hline Name & Description \\
\hline Evf_length & Perimeter of the central pivot, in meters \\
Area & Area of the central pivot, in hectares \\
Orbit-point & Location of center pivot at the scene of the CBERS grid \\
Data & Date of acquisition of base image \\
Municipality & Location of center pivot at the city division \\
UP_IGAM & Location of center pivot at Minas Gerais planning units \\
\hline
\end{tabular}




\section{RESULTS AND DISCUSSION}

Mapping of center pivots in the state of Minas Gerais allowed determining not only the number of installed equipment, but also its location and area, revealing the areas of highest concentration of center pivots in the state.

Center pivots identified in the area of study accounted for 3,781 units, encompassing a total area of approximately 254,875 ha. Comparing these data with those estimated by SCHMIDT et al. (2004), one notices an increase of approximately 52\% in the number of devices. Relating also the area occupied by these equipments during the study period with the estimation made by CHRISTOFIDIS (2008), it is observed an increase of almost three times in the area irrigated by center pivots.

According to SCHMIDT et al. (2004), the margin of error related to counting the number of pivots when using satellite images is not higher than 5\%, but it is influenced by image resolution, size of the pivot, cloudiness, image overlapping and the lack of contrast between the occupation and the neighboring soil. Given this margin of error, the total number of pivots in the state of Minas Gerais would vary between 3682 and 4060 units.

Figure 3 shows the estimated concentration of pivots in the Planning Units, the units of Water Resources Management (UPGRH) and in the basins of Minas Gerais.

Of the 853 municipalities of Minas Gerais, 180 presented areas irrigated by center pivot. Three cities were selected because they presented over 100 devices: Paracatu, Unaí and Rio Paranaíba, each with 495, 459 and 197 center pivots, respectively.

PEREIRA et al. (2009), using the technique of visual classification of images from the satellites CBERS2B/CCD and LANDSAT5/TM, in the years 2008 and 1998, respectively, to assess the number and the area irrigated by center-pivot systems in the municipality of Unaí, reported an increase of 17,762.62 ha of the irrigated area by these systems and a number of equipment estimated at 394 for the year 2008. The discrepancy between the results of this work and the one performed by PEREIRA et al. (2009) can be explained by the use of images from different dates. OZDOGAN et al. (2010) report that the mapping of irrigated areas on a local scale by using remote sensing is strongly affected by image acquisition time and also by the number of images used.

In order to compose the municipality of Unaí, four CBERS/CCD images were required, with the path rows $155 / 119,156 / 118,156 / 119,157 / 118$. In Figure 1, it can be observed that these two scenes (156/118 and 157/118) were obtained in 06/2009 and 09/2009, while PEREIRA et al. (2009) used images obtained from $07 / 2008$ for the same path rows. If not taken into account the difference in interpretation of each author, one can conclude that there was an increase of 65 irrigation systems in this municipality from 2008 to 2009 . 

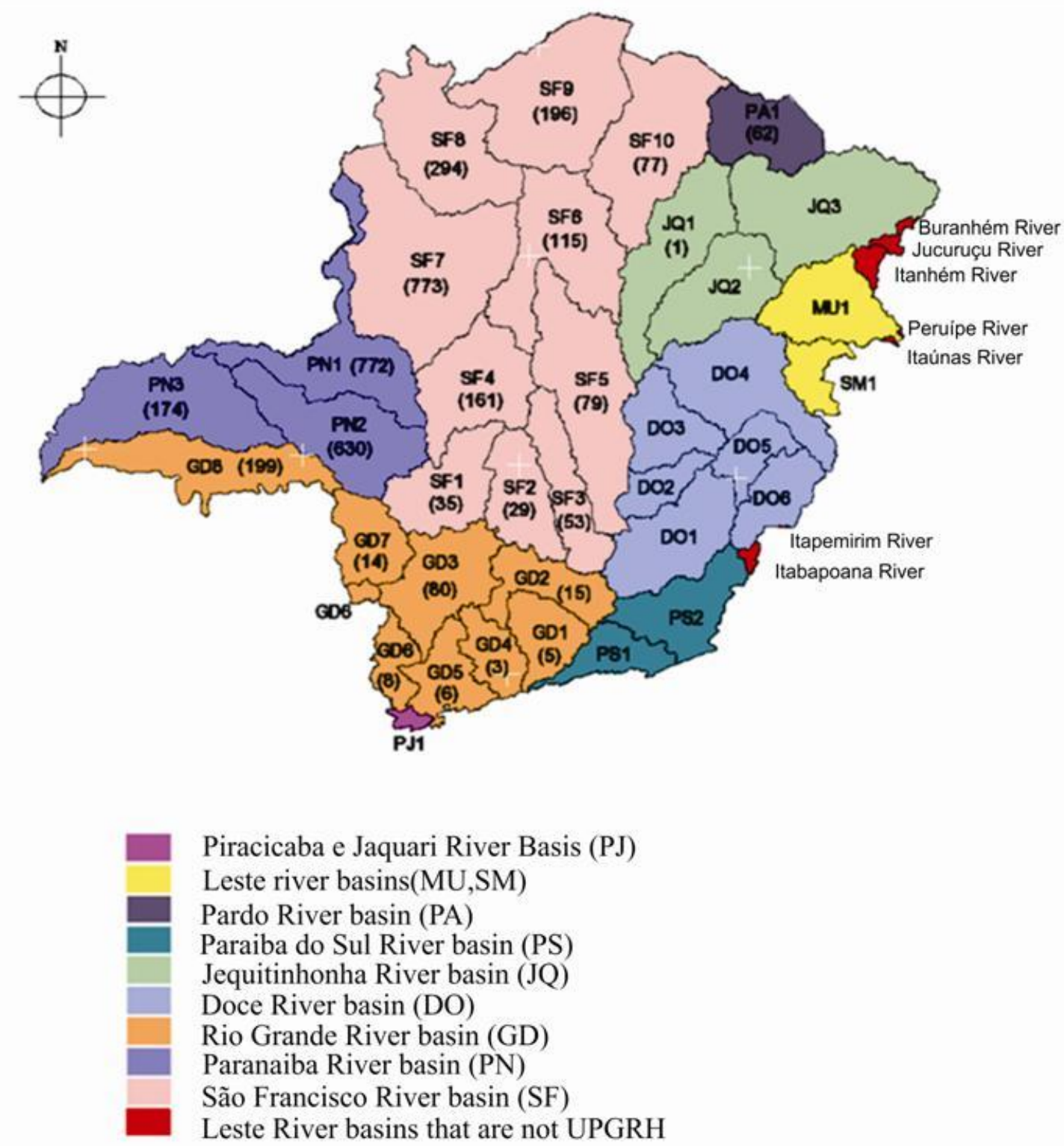

FIGURE 3. Center pivots distribution per Planning Unit (UP) and the basins of the State of Minas Gerais. The number in brackets refers to the amount of equipment by the UP.

Figure 4 shows the distribution of center pivots found in the basins of the State of Minas Gerais. It may be noted that most systems are concentrated in the drainage basins of the São Francisco and Paranaíba Rivers, with 1812 and 1576 systems, respectively. The basins of the Grande, Pardo and Jequitinhonha Rivers had 330; 62 and 1 (one) irrigation system, respectively. The basins of the Leste Rivers, Piracicaba and Jaguari Rivers, Paraíba do Sul River, and Doce River, which does not compose UPGRH, showed no equipment installed.

Figure 5 shows the number of devices found in each class of area irrigated by pivot, being divided into: less than 50 ha, between 50 and 100 ha, between 100 and 150 ha and more than 150 ha. It can be seen from this figure that 1,828 systems ( $47 \%$ of the pivots) irrigate areas between 50 and 100 hectares. A significant number of pivots (1,277 devices) irrigate areas smaller than 50 ha, and that only 47 systems irrigate areas larger than 150 hectares. The largest estimated area for an equipment was 192.6 ha with six devices with this size, being two of them installed in the municipality of Unaí (Paranaiba River Basin), and four of them in Paracatu (São Francisco River Basin). The smallest equipment comprised 4.6 ha and is located in the municipality of Centralina, at the Paranaíba River Basin. 


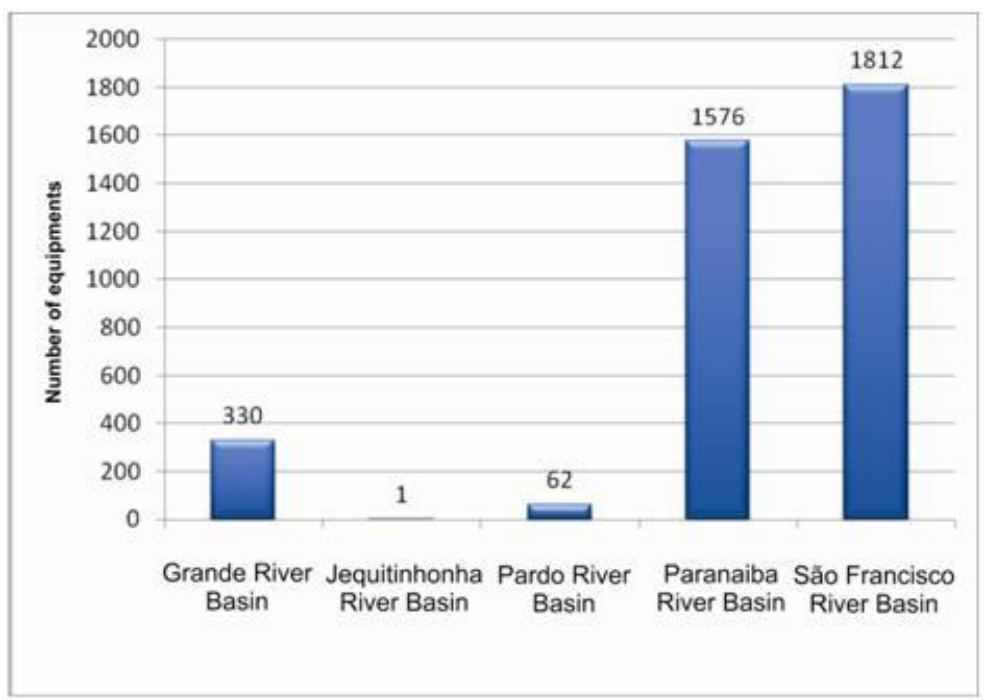

FIGURE 4. Concentration of center pivots in the basins of the State of Minas Gerais.

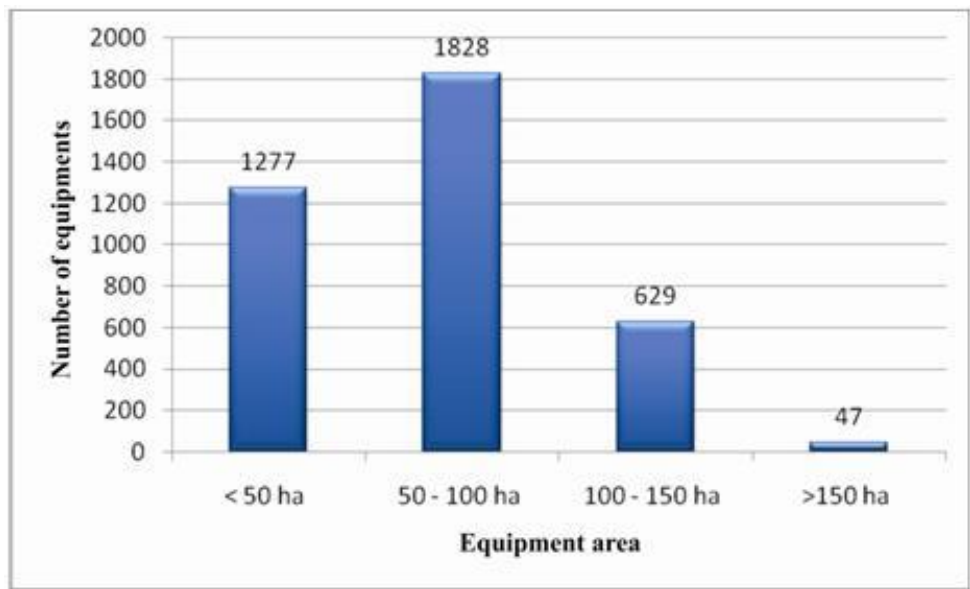

FIGURE 5. Number of equipment by class of center pivot irrigated area.

In Figure 6, it can be observed that $52 \%$ of the irrigated area in Minas Gerais is carried out by center pivots that have areas ranging from 50 to 100 hectares. Although there is a large number of devices with areas smaller than 50 ha (1277 pivots), the area irrigated by these systems corresponds to only $17 \%$ of the total irrigated area (Figures 5 and 6). Still in Figures 5 and 6, it can be noticed that devices encompassing between 100 and 150 ha (629 sets) represent $29 \%$ of the total irrigated area.

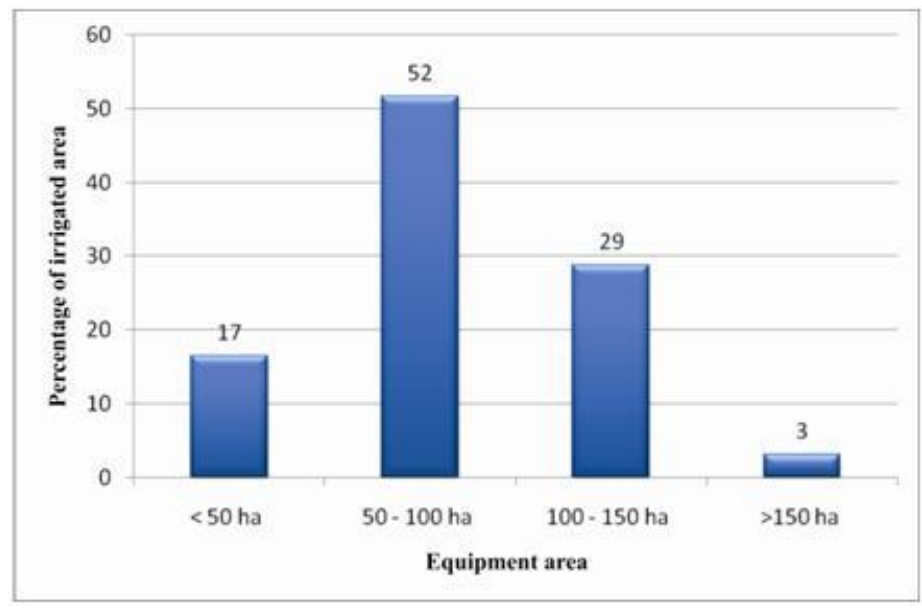

FIGURE 6. Percentage of irrigated area in Minas Gerais State related to the size of the area irrigated by equipment. 


\section{CONCLUSIONS}

We identified 3,781 center pivot systems in Minas Gerais state. The smallest irrigated area was 4.6 hectares and the largest one was 192.6 hectares. The estimated total irrigated area was 254,875 ha.

Regarding the distribution of center pivots, we observed that the municipalities and Unaí and Paracatu had the highest number of center pivots, with 495 and 459, respectively; most systems (90\%) was concentrated in the Paranaíba River and São Francisco River basins, with 1576 and 1812 systems, respectively.

Of the total installed pieces of equipment, 3,105 irrigate areas up to 100 hectares account for $69 \%$ of the area irrigated by center pivot in the State of Minas Gerais.

This study confirms that the use of remote sensing associated with geographic information systems (GIS) is a compelling technique for mapping irrigated areas by central pivots, allowing for the identification and registration of these areas, resulting in considerable saving of resources, because it does not require field surveys, which are expensive and time consuming.

\section{ACKNOLEDGMENTS:}

To Fundação de Amparo à Pesquisa do Estado de Minas Gerais (FAPEMIG), process n. CAG-APQ-02004-09.

\section{REFERENCES}

BRAGA, A.L.; OLIVEIRA, J.C. Identificação e quantificação de áreas irrigadas por pivô central utilizando imagens CCD/CBERS. In: SIMPÓSIO BRASILEIRO DE SENSORIAMENTO REMOTO, 12., 2005, Goiânia. Anais... São José dos Campos: Instituto Nacional de Pesquisas Espaciais, 2005. 1 CD-ROM.

CAI, X.; ROSEGRANT, M.W. Global water demand and supply projections. Water International, Urbana, v.27, p.159-169, 2002.

CÂMARA, G.; SOUZA, R.C.M., FREITAS, U.M.; GARRIDO, J. Spring: Integrating remote sensing and GIS by object-oriented data modelling. Computers \& Graphics, New York, v.20, n.3, p.395-403, 1996.

CHRISTOFIDIS, D. Água: um desafio para a sustentabilidade do setor agropecuário. Brasília, 2008. 11 p. (Série Irrigação e Água, 1-2007). Disponível em: < http://www.irrigacao.org.br/artigos/ demetrios_agrianual.pdf >. Acesso em: 18 ago. 2010.

CURADO, R.F.; FERREIRA, E. Uso do aplicativo SPRING no auxílio à gestão fundiária: o caso do Estado do Tocantins. Ciência e Agrotecnologia, Lavras, v.27, n.5, p.1097-1104, 2003.

CURADO, R.F.; FERREIRA, E.; LIMA, J.M. Mapeamento cadastral de imóveis rurais em duas sub-bacias hidrográficas no Município de Lavras, MG. In: CONGRESSO BRASILEIRO DE CADASTRO TÉCNICO MULTIFINALITÁRIO, 6., 2004, Florianópolis. Anais... Florianópolis: UFPR, 2004. 1 CD-ROM.

OLIVEIRA, L. de; TALAMINI, E. Water resources management in the Brazilian agricultural irrigation. Journal of Ecology and the Natural Environment, Nairóbi, v.2, n.7, p.123-133, 2010.

OZDOGAN, M.; YANG, Y.; ALLEZ, G.; CERVANTES, C. Remote sensing of irrigated agriculture: opportunities and challenges. Remote Sensing, Ottawa, v.2, p.2274-2304, 2010.

PEREIRA, R.M.; FERREIRA, E.; DANTAS, A.A.A.; SOUZA, P.A.B.; FRANÇA JUNIOR, J.F. Avaliação temporal de áreas irrigadas por pivôs centrais no município de Unaí. In: CONGRESSO DE INICIAÇÃ̃ CIENTÍFICA, 22., 2009, Lavras. Anais... Lavras: Universidade Federal de Lavras, 2009. 1 CD-ROM. 
PONZONI, F.J.; ALBUQUERQUE, B.F.C. Pre-Launch Absolute Calibration of CCD/CBERS-2B Sensor. Sensors, v.8, p. 6557-6565, 2008.

SANO, E.E.; LIMA, J.E.F.W.; SILVA, E.M.; OLIVEIRA, E.C. Estimativa da variação da demanda de água para irrigação por pivô central no Distrito Federal entre 1992 e 2002. Revista Engenharia Agrícola, Jaboticabal, v.25, n.2, p.508-515, 2005.

SCHMIDT, W.; COELHO, R.D., JACOMAZZI, M.A.; ANTUNES, M.A.H. Distribuição espacial de pivos centrais no Brasil: I - Região Sudeste. Revista Brasileira de Engenharia Agrícola e Ambiental, Campina Grande, v.8, n.2-3, p.330-333, 2004.

XAVIER, S.C.; BASTOS, C.A.B. Estudo do crescimento urbano aplicado ao mapeamento geotécnico: uma metodologia de análise. Revista Brasileira de Cartografia, Curitiba, n.62, v.4, p.583-593, 2010. 